\title{
The Influence of Polyphenol Compounds on Human Gastrointestinal Tract Microbiota
}

\author{
Michał Wiciński ${ }^{1}$, Jakub Gębalski ${ }^{1, *}$, Ewelina Mazurek ${ }^{1}$, Marta Podhorecka ${ }^{2}{ }^{\oplus}$, \\ Maciej Śniegocki ${ }^{3}$, Paweł Szychta ${ }^{4}$, Ewelina Sawicka ${ }^{1}$ and Bartosz Malinowski ${ }^{1}$ \\ 1 Department of Pharmacology and Therapeutics, Faculty of Medicine, Collegium Medicum in Bydgoszcz, \\ Nicolaus Copernicus University, 85-090 Bydgoszcz, Poland; michal.wicinski@cm.umk.pl (E.W.); \\ ewelhan@gmail.com (E.M.); ewelina.sawicka@cm.umk.pl (E.S.); bartosz.malinowski@cm.umk.pl (B.M.) \\ 2 Department of Geriatrics, Faculty of Health Sciences, Collegium Medicum in Bydgoszcz, Nicolaus \\ Copernicus University, 85-090 Bydgoszcz, Poland; marta.podhorecka@cm.umk.pl \\ 3 Department of Neurosurgery, Neurotraumatology and Paediatric Neurosurgery, Faculty of Medicine, \\ Collegium Medicum in Bydgoszcz, Nicolaus Copernicus University, 85-090 Bydgoszcz, Poland; \\ sniegocki.m@gmail.com \\ 4 Department of Plastic, Reconstructive and Aesthetic Surgery, Faculty of Medicine, Collegium Medicum in \\ Bydgoszcz, Nicolaus Copernicus University, 85-090 Bydgoszcz, Poland; drszychta@gmail.com \\ * Correspondence: jakubgebalski@gmail.com
}

Received: 29 December 2019; Accepted: 26 January 2020; Published: 29 January 2020

\begin{abstract}
Polyphenols form a diverse group of compounds containing at least two hydroxyl groups in their chemical structure. Because of the common presence in plant kingdom, polyphenols are considered a significant component of food and an important group of compounds with antioxidant properties. The absorption of polyphenols present in food depends mostly on the activity of intestinal microflora. However, little is known about the processes and interactions responsible for such phenomenon in guts ecosystem. There are only few available publications that examine the effect on polyphenols on intestinal microbiota. Therefore, this work will focus on describing the relationship between polyphenol compounds present in food and bacteria colonizing the intestines, their mechanism, and impact on human's health.
\end{abstract}

Keywords: polyphenols; gut microbiota; probiotics; antioxidants

\section{Introduction}

Intestinal Microflora

In human's gastrointestinal tract, there are over one thousand species of bacteria. The representatives of eukaryotes and prokaryotes such as Firmicutes, Bacteroidetes, Actinobacteria, and Proteobacteria form a permanent or temporary component of microbiota [1]. Among them there are symbiotic and commensal microorganisms, but also those that can cause diseases. Intestinal microflora take part in creating short-chain fatty acids (SCFAs) and branched-chain fatty acids (BCFAs) that are important nutrients for intestinal cells [2]. SCFAs not only stimulate division and differentiation of enterocytes, but also regulate and maintain the mineral balance of organism and promote iron, calcium, and magnesium absorption [3]. The products that are created during fermentation of microorganisms regulate metabolism of lipids and glucose [4]. Microflora of gastrointestinal tract stimulates the synthesis of mucin, which protects organisms from toxic substances and pathogens [5]. The protective function of the intestine is also connected to the degradation of toxins and insulation of its walls. The microorganisms colonizing human's gut are responsible for modulating the immune system [6] and participate in the production of vitamins such as B and K. Despite of all the above-mentioned 
benefits, the bacteria could also cause negative changes in health. Abnormal microflora can impact the growth of neoplasm in gastrointestinal tract, mainly in the large intestine due to production of mutagens and carcinogens (E. coli, E. faecalis, Basteroides) [7]. Low content of fiber, high content of protein and fats, but also unhealthy, highly processed food can cause disturbance of microbiota [8]. Moreover, taking medications such as antibiotics, chemotherapeutics, non-steroidal anti-inflammatory drugs, proton pump inhibitors, antineoplastic agents, stress, infections, and stimulants might affect microflora in a similar way to incorrect food content $[9,10]$. The possible effect of such a disturbance is the development of allergy [11] or diabetes mellitus type 1 [12]. Additionally, recent studies show the connection between intestinal microbiota and the central nervous system where the imbalance might be a possible cause of mental diseases e.g., depression $[13,14]$. Dysbiosis in gastrointestinal tract can also affect metabolic disorders and have an impact on obesity [12], heart diseases, and diabetes mellitus type 2 [15].

\section{Phenol Compounds}

Phenols represent a very important group of antioxidant compounds, widespread among plants [16] that arise as products of plants' metabolism in the wake of stress, damage, infection, or UV radiation. They are a cohort of compounds of diversified chemical structure emergent in two pathways. In shikimic acid's transformation, hydroxycinnamic acids and coumarins come into existence. Simple structure polyphenol compounds are made of acetic acid. Structurally more complex flavonoids are formed as a result of these two routes (Figure 1). [17].

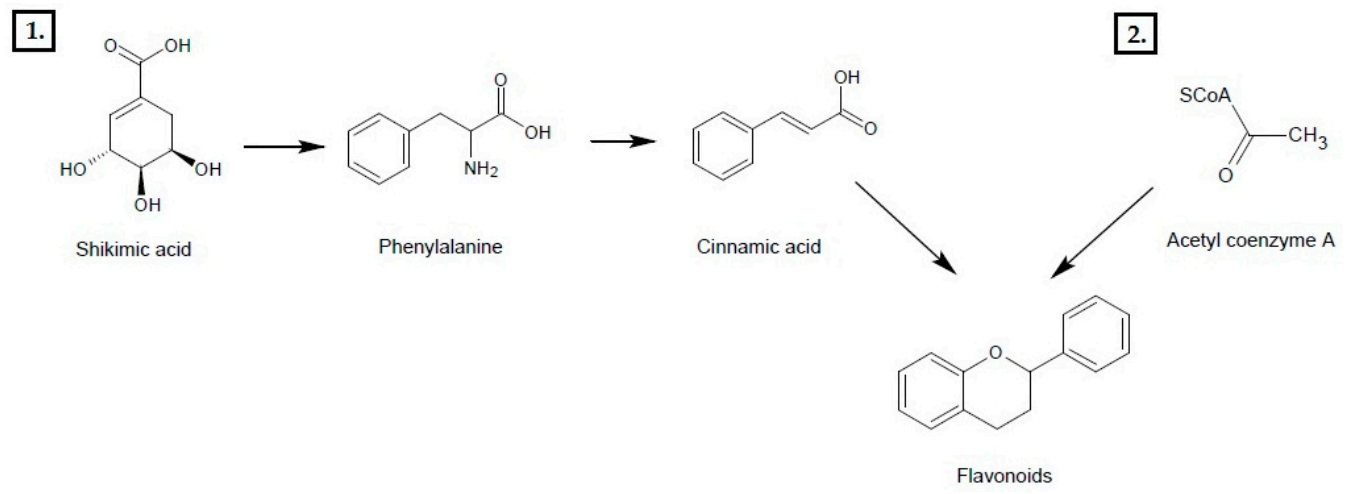

Figure 1. Biosynthesis of Flavonoids. 1. The shikimic acid pathway; 2. The acetate pathway.

Due to the composition, polyphenol compounds might be differentiated into phenolic acids, flavonoids, stilbenes, and lignans (Table 1) [18]. Flavonoids are a large group of compounds composed of two benzene rings connected by a tri-carbon chain or heterocyclic ring [19]. Flavonoids can occur in two forms: Free - aglycons, or in the form of $\beta$-glycosides [combination of aglycone with the sugar part] [19]. Aglycones of most flavonoids are more hydrophobic than their glycosides [20]. They can penetrate the biological membranes of enterocytes as a result of passive transport [20]. The presence of a glycosidic substituent in the flavonoid molecule causes an increase in its mass and hydrophilicity, which limits its absorption as a result of diffusion [21]. Flavonoid compounds that have not been absorbed in the upper digestive tract reach the large intestine, where they are modified by bacterial enzymes [22]. These compounds can be metabolized by $\beta$-glucosidase, $\alpha$-rhamnosidase, and $\beta$-galactosidase, synthesized by bacteria [23]. The resulting flavonoid aglycons can be absorbed in the large intestine or further metabolized [24]. As a result of metabolism, many low-molecular phenolic compounds, such as phenylacetic and phenylpropanoic acids, are formed [25]. Polyphenols commonly occur in plants; they are a significant ingredient of food. Fruits, especially berries, strawberries, raspberries, and chokeberry are abundant sources of them. Polyphenols occur in a fruit juice as well. Content in these products depends on the stage of manufacture. Juices made of freshly extruded fruits contain distinctly more polyphenols in comparison to manufactured concentrates [26]. 
Vegetables are a rich source of polyphenol compounds than fruits, mostly phenolic acids. Garlic, onion, broccoli, red cabbage, and red pepper pose the best source of them [27]. Green and black tea are rich in epicatechin, catechin, kaempferol, and quercetin [28]. Polyphenols' antioxidant properties are connected to the presence of many hydroxyl groups, and thanks to this characteristic they protect plants from free radical actions. There are two mechanisms of polyphenol antioxidant action. Polyphenol reaction with radicals leads to the rise of a phenol radical, which due to a low reactivity does not cause any threat to the cells [29]. Antioxidant properties of polyphenol compounds result from the ability of metal chelation [30]. Transition metals (especially iron and copper) are elements present in many proteins and act out an important role in the functioning of the cells. Those metals are involved in Fenton's reaction [31], which consists of two stages. The first one is the reaction between metal and hydrogen peroxide forming hydroxyl radical. Afterwards, the reduction of oxidized metal by superoxide anion takes place [32]. The arisen hydroxyl radical is a reactive form of oxygen that reacts with most of the compounds present in the cell e.g., protein, fatty acids, nucleic acids, or small metabolites [33]. Polyphenols inhibit the activity of oxidases, which catalyze the formation of water or hydrogen peroxide [34]. However, in specific situations, they can show prooxidase action via reduction of transition metals that allows catalysis of Fenton's reaction (Figure 2) [35].

Table 1. The classification of natural polyphenols [36,37]

\begin{tabular}{|c|c|c|c|}
\hline Class & Subclass & Examples of Compounds & Source \\
\hline \multirow[t]{2}{*}{ Phenolic acids } & Hydroxycinnamic acids & $\begin{array}{l}\text { Curcumin } \\
\text { Caffeic acid } \\
\text { Ferulic acid }\end{array}$ & Fruit and cereals \\
\hline & Hydroxybenzoic acids & $\begin{array}{c}\text { Gallic acid } \\
\text { Protocatechuic acid } \\
\text { Vanillic acid }\end{array}$ & Onion, raspberry, blackberry, strawberry \\
\hline \multirow{6}{*}{ Favonoids } & Flavonols & $\begin{array}{l}\text { Kaempferol, } \\
\text { Quercetin, } \\
\text { Myricetin }\end{array}$ & Onions, tea, lettuce, broccoli, apples \\
\hline & Flavanones & $\begin{array}{l}\text { Naringenin, } \\
\text { Hesperetin }\end{array}$ & Oranges, grapefruits \\
\hline & Flavanols & $\begin{array}{l}\text { Gallocatechin } \\
\text { Catechins }\end{array}$ & Tea, red wine, chocolate \\
\hline & Isoflavones & $\begin{array}{l}\text { Genistein, } \\
\text { Glycitein, } \\
\text { Daidzein }\end{array}$ & Soybeans, legumes \\
\hline & Anthocyanins & $\begin{array}{l}\text { Pelargonidin, } \\
\text { Delphinidin, } \\
\text { Malvidin }\end{array}$ & Blackcurrant, strawberries, red wine, chokeberry \\
\hline & Flavones & $\begin{array}{l}\text { Apigenin, } \\
\text { Luteolin, }\end{array}$ & Parsley, celery, red pepper, lemon, thyme \\
\hline Stilbenes & & Resvertrol & Red wine \\
\hline Lignans & & $\begin{array}{c}\text { Pinoresinol, } \\
\text { Lariciresinol, Secoisolariciresinol, Sesamin }\end{array}$ & Flax seed, sesame seed, red wine \\
\hline
\end{tabular}

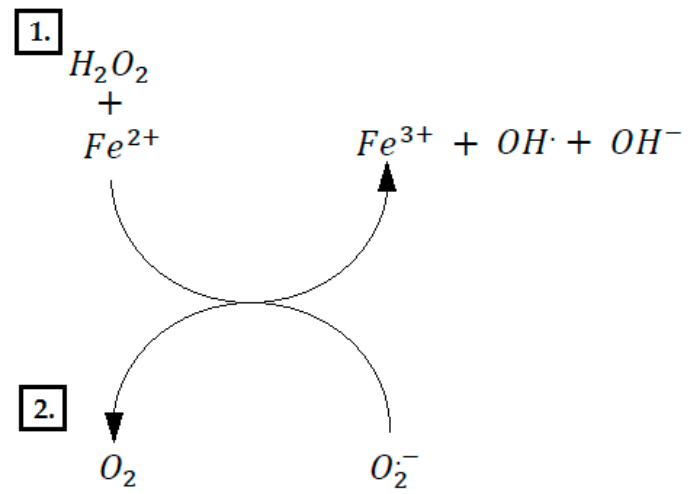

Figure 2. Fenton's cycle. 1. $\mathrm{H}_{2} \mathrm{O}_{2}$ is broken down into $\mathrm{OH}$ and $\mathrm{OH}^{-}$in the presence of $\mathrm{Fe}^{2+} 2$. Reduction of $\mathrm{Fe}^{3+}$ to $\mathrm{Fe}^{2+}$ by superoxide anion radical. 


\section{The Influence of Polyphenol Compounds Contained in Tea on Intestinal Microflora.}

Tea, one of the most popular drinks in the world, is high in polyphenols such as catechin, epicatechin, and quercetin. Moreover, it is known for its antitumor properties, especially in the case of large intestine cancer. Several studies tried to examine the influence of polyphenol compounds present in tea on bacteria in gastrointestinal tract. Tzounis et al. [38] examined the influence of monomers of flavan-3-ols like (-) epicatechin and (+) catechin on fecal bacterial growth (Table 2). The experiment was carried out in conditions that correspond to those present in the human intestine with the usage of two doses, respectively $150 \mathrm{mg}$ and $1000 \mathrm{mg}$. Presence of (+) catechin stimulated the growth of Clostridium coccoides-Eubacterium rectale, Bifidobacterium spp., and Escherichia coli, but at the same time inhibited the growth of $C$. histolyticum. In comparison, (-) epicatechin stimulated only the growth of population of C. coccoides-Eubacterium rectale. Due to prebiotic properties, the consumption of food enriched form polyphenols contributes to gut integrity and intestinal homeostasis [39]. Growth of the group Clostridium coccoides-Eubacterium rectale is beneficial for the host due to increased production of short-chain fatty acids (SCFAs) used by the cells as a source of energy [40]. SCFAs formed by bacteria also inhibit proliferation of tumor cells and accelerate conversion of cholesterol into bile acids [41]. Growth of Bifidobacterium spp. was minor, but statistically significant as those bacteria inhibit proliferation of pathogens by production of organic acids [42]. Moreover, decrease in a population of C. histolyticum could be observed. Those bacteria due to the proteolytic properties can redound to the progression of colon cancer and development of inflammatory bowel diseases such as Crohn's disease or ulcerative colitis. Therefore, decline in the number of $C$. histolyticum brings benefits for the host. The mechanism of this process is connected to degradation of proteins. Undigested proteins undergo the fermentation in the large intestine; the process is carried out by proteolytic bacteria (mainly Bacteroides and Propionibacterium) during which ammonia, thiols, amines, phenol, and indole compounds are formed. Additionally, Amines in the nitrosation reaction can form carcinogens such nitrosamines. Phenol and indole compounds negatively affect intestinal epithelium as they stimulate development of cancer by increasing the strength of carcinogenic factors [43,44]. In contrast to glycosides in food that do not seem to cause any harm in the host organism, flavonoid aglycones present mutagenic and toxic effects. The contradiction in the results of the influence of flavonoid aglycones on human health is connected with the transformation to compounds either working profitably or unfavorably for the host [45].

In Goto et al.'s study [46], the polyphenols present in tea has a positive effect on the growth of Bifidobacterium spp.. Decline in the number of putrefactive bacteria like Enterobacteriaceae spp. and Clostridium spp. was noticeable as well. The consumption of tea evidently improved conditions in the intestines by lowering the levels of sulfides, ammonia, and $\mathrm{pH}$.

In Lee et al.'s experiment [47], the main aim was to examine the effect of polyphenols and their aromatic metabolites on bacterial growth. A significant inhibition of the growth of Clostridium perfringens, Clostridium difficile, E. coli, Salmonella, and Staphylococcus spp was observed. The examined compounds were also inhibited, but in a smaller extent. The growth of probiotic bacteria e.g., Clostridium spp., Bifidobacterium spp., Lactobacillus spp was noticed.

\section{The Influence of Polyphenols Present in Plant Extracts on Microbiota}

Plant extracts form a large class of compounds with multi-directional effects on human health. Their properties are the sum of individual functions of complexes included in a specific extract. Commonly, together with polyphenols, other antioxidants like vitamin C, E, and carotene are present. Those substances have protective properties towards different tissues. The pharmaceutic industry offers abundant numbers of products containing distinct plant extracts used as a prevention or treatment in conditions like cardiovascular disease, liver dysfunction, and to mitigate symptoms of menopause.

Yamakoshi et al. [48] studied the effect of grapes' seeds extract that contained, respectively, $89.3 \%$ and $38.5 \%$ proanthocyanidins on intestinal bacteria. The beverage was administered to two groups for two weeks. The number of Bifidobacterium increased when at the same time, the colony 
of Enterobacteriaceae decreased. Bifidobacterium as bacteria exhibit positive effects on human health through the formation of SCFAs, but also by lowering the $\mathrm{pH}$ and inhibiting the development of putrefactive bacteria.

Since intestinal microflora is very sensitive and easily detects changes in external conditions, it is of high importance to supplement with substances such as prebiotics (non-absorbable compounds) that stimulate growth of one or few groups of beneficial bacteria in colon [49].

Tzounis et al. [50] evaluated the influence of flavonols derived from cocoa with the potential of being used as prebiotics. Patients were divided into two groups where the first one obtained $494 \mathrm{mg}$ of cocoa flavonols per day and the other group was given $23 \mathrm{mg}$ of the same flavonols daily for the period of four weeks. Researchers determined a statistically significant growth of Bifidobacterium and Lactobacillus. Both types of bacteria inhibit development of pathogenic microorganisms. Moreover, studied extract affected the population of $C$. histolyticum by relevantly decreasing it. Cocoa-derived flavonols can also inhibit the growth of Clostridium perfringens that might contribute to progression of colon cancer and participate in arising of inflammatory bowel disease. The change in intestinal microflora was connected to a change in the level of triglycerides in patients' blood. Therefore, the study confirms the possibility of applying the polyphenols as a potential prebiotic compound.

\section{The Effect of Polyphenols Contained in Wine on Intestinal Microflora}

Red wine is a source of multiple polyphenol compounds e.g., catechin, proanthocyanidins, stilbenes, anthocyanins, and flavonols that exhibit cardioprotective and antioxidant properties. Despite many studies on the mechanism of action of red wine, the contribution of individual components was not unequivocally determined. Compounds that potentially have the greatest meaning are resveratrol, phenolic acids, and proanthocyanidins. The positive effect of red wine on the gut microbiota is due to prebiotic activity and inhibition of pathogen growth [51].

Queipo-Ortuno et al. [52] analyzed the effect of consumption of red wine on intestinal microbiota. For four weeks, they studied the influence of wine $(272 \mathrm{~mL})$, non-alcoholic wine $(272 \mathrm{~mL})$, and alcohol $(250 \mathrm{~mL})$. There was a significant growth of Enterococcus, Prevotella, Bifidobacterium, Bacteroides uniformis, Eggerthella lenta, and group Blautia coccoides-Eubacterium rectale in patients receiving red wine. Simultaneously, during this study, blood pressure measurements and lipid concentration tests were carried out on patients. The obtained results showed some beneficial effects of polyphenols present in wine on circulatory system and lipid profile. Not only systolic and diastolic blood pressure, but also the concentration of triglycerides, total cholesterol, and HDL cholesterol significantly declined. Those changes could be associated with the growth of a species Bifidobacterium spp. Bifidobacteria can produce short-chain fatty acids capable of reducing cholesterol synthesis in the liver or can bind bile acids in the digestive tract [53]. The obtained results present some potential advantages of the usage of red wine polyphenols as a prebiotic source. The experiment did not detect any effect of wine or alcohol on the growth of Lactobacillus spp., while consumption of alcohol ensued from increase in proliferation of Bacteroides spp. and Clostridium spp. Additionally, the disappearance of Prevotellaceae spp. population in comparison with red wine and non-alcoholic wine occurred. The concentration of uric acid considerably decreased when patients received red wine possibly as a result of the growth of Proteobacteria that degrade the mentioned compound [54]. Lowering of CRP concentration after non-alcoholic and red wine period might be connected to the increase in the number of Bifidobacterium spp., and the change in the recalled parameter can indicate an advantageous effect of wine polyphenols on cardiovascular system [55].

A similar study was carried by Moreno-Indias et al. [56] where researchers examined prebiotic effect of red wine on intestinal microbiota and reduction of metabolic syndrome markers in obese patients. In this study, red wine $(272 \mathrm{~mL})$ and non-alcoholic wine $(272 \mathrm{~mL})$ were tested. After the period of red and non-alcoholic wine consumption, in patients with a metabolic syndrome, scientists observed a relevant increase in the number of Fusobacterium and Bacteroidetes while at the same time, a significant decline in the population of Firmicutes was noticed. Likewise, in the group of healthy subjects, 
a statistically important growth of Bacteroidetes in comparison with the initial value was noticeable. In the case of patients with dysmetabolic syndrome $X$, during red as well as non-alcoholic wine consumption, researchers registered decline in Clostridium and Clostridium histolyticum species that are within Firmicutes phylum. At the same time, a growth of bacteria in the group of Blautia coccoides-Eubacterium rectale, Faecalibacterium prausnitzii, Roseburia, and Lactobacillus was noticed. In healthy patients, scientists observed an increase in the number of Faecalibacterium prausnitzii and Roseburia.

In the study conducted on obese women and men, a significant decrease in the number of Bacteroidetes and a tendency to reduce the number of Faecalibacterium prausnitzii in men was noted. These changes were not observed in women. The differences may be due to hormonal changes [57]. Faecalibacterium prausnitzii belongs to the group of important SCFA producers [58]. A decrease in the number of these bacteria is observed in patients with inflammatory bowel disease [IBD] [59]. The most common diseases from this group are Leśniowski-Crohn's disease and ulcerative colitis [59]. In IBD, the excessive activation of the immune system is increased by pathogenic bacteria [60]. Additionally, SCFA-inducing interleukin 10 [IL-10] reduces inflammatory reactions [60]. Akkermansia muciniphila is an important factor modulating F. prausnitzii count. A. muciniphila degrades mucus components to propionic acid, acetic acid, and oligosaccharides, which are used by F. prausnitzii [61]. Numerous clinical studies have investigated the benefits of polyphenol supplementation (anthocyanins, epigallocatechin gallate, resveratrol, and curcumin) in patients with IBD. The improvement of patients' health resulted from multidirectional actions such as regulation of cytokine concentration, antioxidant enzymes, and modification of intestinal microflora [62,63]. Anthocyanins are natural pigments widespread in plant kingdom and are present in flowers, fruit peel, or in wine where they impart the color. Hidalgo et al. [64] determined the influence of mixture of anthocyanins, 3-glucoside of malvidin (oenin), and gallic acid on bacterial growth. The use of oenin on microorganisms caused the increase in the total number of bacteria. Scientists demonstrated the growth in population of $C$. coccoides-Eubacterium rectale that is responsible for production of SCFA. The usage of mixture of anthocyanins of low concentration on studied bacteria had a positive correlation with the growth of Bifidobacterium spp. and Lactobacillus spp. but did not affect $C$. coccoides-Eubacterium rectale and C. histolyticum populations. Gallic acid used in the experiment inhibited the growth of $C$. histolyticum without any negative consequences on the beneficial bacteria population in intestines. Moreover, it considerably increased the total number of bacteria and specific species called Atopobium spp., which is significant in gastrointestinal tract as Atopobium minutum induces the process of apoptosis of colon cancer cells. Therefore, the growth of this bacteria suggests a positive effect on human health [65]. Anthocyanins and their metabolites present in large intestine, increase the number of Lactobacillus spp. and Bifidobacterium spp. These bacteria have an ability to metabolize phenol complexes during augmentation, supplying energy to the cells and enriching the environment for other bacteria. Hence, anthocyanins, mainly the mixture of anthocyanins derived from grapes, might function as a stimulator for growth of Lactobacillus spp. and Bifidobacterium spp. that have a positive effect on large intestine. The increase in number of lactic acid bacteria in colon reduces the creation of procarcinogens in the large intestine, and lowers $\mathrm{pH}$ and cholesterol levels in patients (Figure 3).

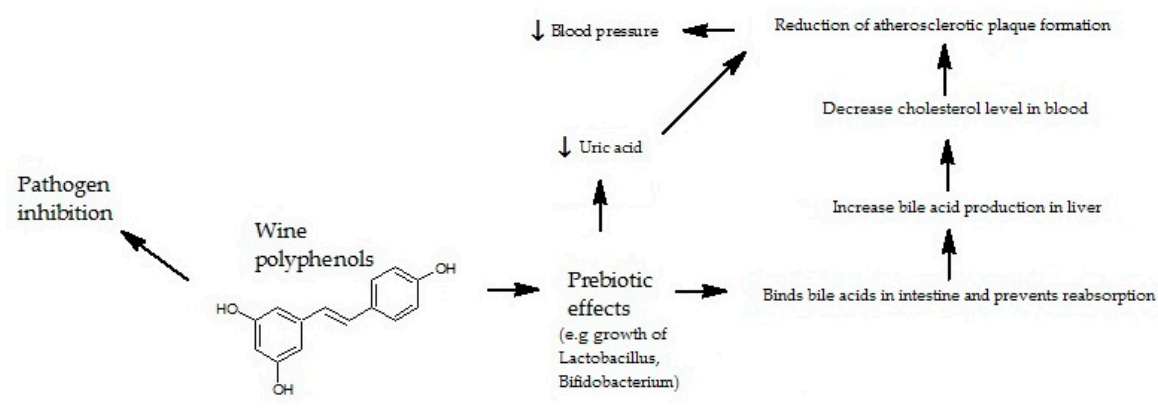

Figure 3. Interaction between wine polyphenols and gut microbiota. 


\section{Polyphenols' Negative Impact on Microflora of Intestines}

Polyphenols act positively on a composition of intestines' microflora and have a beneficial impact on human health. The impact of polyphenols on bacterial growth depends on the dose, structure, as well as phylum of bacteria [66]. Gram-negative are more resistant to polyphenols than gram-positive due to the differences in the cell wall structure [67]. The antibacterial effect is connected with various mechanisms, for instance cell wall damaging [68], $\mathrm{H}_{2} \mathrm{O}_{2}$ production [69], or changes in permeability of cell membrane [70]. Polyphenol compounds might derange quorum sensing [71]. Another hypothesis envisages the creation of metal-polyphenol compounds. The lack of iron suppresses the growth of sensitive bacteria, mostly aerobic microbes [72]. In Firmann et al.'s study [73] the influence of quercetin on intestinal commensal bacteria such as Ruminococcus gauvreauii, Bifidobacterium catenulatum and Enterococcus caccae, was evaluated. Outcome of studies show that quercetin does not influence the growth of Ruminococcus gauvreauii but mildly hinder the growth of Bifidobacterium catenulatum and Enterococcus caccae. The study held by Duda-Chodak [74] ascertained negative effect of aglycons (naringenin, hesperetin, quercetin, and catechin) and glycosides (naringin, hesperidin, and rutin) on intestinal microbiota represented by Bacteroides galacturonicus, Lactobacillus spp., Enterococcus caccae, Bifidobacterium catenulatum, Ruminococcus gauvreauii, and Escherichia coli. In this experiment, polyphenols in concentrations of 20,100 , and $250 \mu \mathrm{g} / \mathrm{mL}$ diluted in growth medium were used(for quercetin the concentrations were 4,20 , and $50 \mu \mathrm{g} / \mathrm{mL}$ ). The examined aglycones presented inhibiting properties towards investigated bacteria (dependent on the concentration of the substance in microbiological medium) while glycosides did not exhibit any effect on intestinal microflora. Catechins did not affect the growth of microorganisms. Only the growth of B. catenulatum was slightly slowed down while the growth of E. caccae was stimulated by higher concentrations of catechins.

The study carried by Tabasco et al. [75] evaluated the influence of grapes' polyphenols on the growth of lactic acid bacteria and Bifidobacterium with the usage of three extracts of concentrations 0.25 , 0.5 , and $1 \mathrm{mg} / \mathrm{mL}$, respectively. The experiment showed a dose-dependent inhibition on growth of above-mentioned bacteria.

Puupponen-Pimia et al. [76] determined the effect of pure polyphenols and polyphenols contained in the extract from blueberries on the probiotic bacteria, Escherichia coli and Salmonella. Lactic acid bacteria were more resistant to pure polyphenol compounds than other examined microorganisms, except myricetin, which inhibited the growth of all lactic acid bacteria with no effect on the growth of Salmonella. Phenolic acids in high concentration mainly inhibited the growth of Gram-negative bacteria. The extracts showed the growth-inhibiting effect, mostly towards Gram-negative bacteria These results indicate that the inhibitory effect of the extracts is due to the synergistic action of polyphenols. 
Table 2. The effects of the intake of polyphenols on intestinal bacteria.

\begin{tabular}{|c|c|c|c|c|c|c|c|c|c|c|}
\hline $\begin{array}{c}\text { Examined } \\
\text { Polyphenols }\end{array}$ & Dose & Duration & $\begin{array}{c}\text { Type of } \\
\text { Experiment }\end{array}$ & Subjects & Diet & Diseases & $\begin{array}{l}\text { Medications } \\
\text { Taken }\end{array}$ & $\begin{array}{c}\text { Stimulation of } \\
\text { Bacterial Growth }\end{array}$ & $\begin{array}{c}\text { Inhibition of } \\
\text { Bacterial Growth }\end{array}$ & Reference \\
\hline $\begin{array}{l}(+)-\text { catechin } \\
(-) \text { - epicatechin }\end{array}$ & $150 \mathrm{mg} / 1000 \mathrm{mg}$ & $48 \mathrm{~h}$ & In vitro & & & & & $\begin{array}{c}\text { Escherichia coli } \\
\text { Bifidobacterium spp. } \\
\text { Group } \\
\text { Clostridium } \\
\text { coccoides- } \\
\text { Eubacterium rectale }\end{array}$ & $\begin{array}{l}\text { Clostridium } \\
\text { histolyticum }\end{array}$ & [38] \\
\hline Tea catechins & $300 \mathrm{mg}$ & 6 weeks & $\begin{array}{c}\text { In vivo } \\
\text { [Open label } \\
\text { pilot] }\end{array}$ & $\begin{array}{l}31 \text { females and } 4 \\
\text { males from } 66 \\
\text { to } 98 \text { years of age }\end{array}$ & $\begin{array}{c}38.7 \mathrm{~g} \text { proteins, } \\
21.1 \mathrm{~g} \text { lipids, } \\
191 \mathrm{~g} \text { carbohydrates, } \\
\text { minerals, } \\
\text { and vitamins. }\end{array}$ & $\begin{array}{l}\text { Hypertension, } \\
\text { cerebral stroke, } \\
\text { senile dementia }\end{array}$ & None antibiotics & $\begin{array}{l}\text { Bifidobacterium } \\
\text { Lactobacillus }\end{array}$ & & [46] \\
\hline $\begin{array}{c}\text { (+) - epicatechin } \\
\text { (-) - catechin } \\
\text { 3-O-methylgallic acid } \\
\text { Gallic acid } \\
\text { Caffeic acid } \\
\text { Phloretic acid } \\
\text { 3-Phenylpropionic acid } \\
\text { 4-Hydroxyphenylacetic acid }\end{array}$ & $1 \mathrm{mg} / \mathrm{mL}$ & $24 \mathrm{~h}$ & In vitro & & & & & $\begin{array}{l}\text { Clostridium spp., } \\
\text { Bifidobacterium spp., } \\
\text { Lactobacillus spp. }\end{array}$ & $\begin{array}{c}\text { Clostridium } \\
\text { perfringens, } \\
\text { Clostridium difficile, } \\
\text { Escherichia coli, } \\
\text { Salmonella, } \\
\text { Staphylococcus spp.. }\end{array}$ & [47] \\
\hline $\begin{array}{l}\text { Extract from grapes' seeds } \\
\text { containing proanthocyanidins }\end{array}$ & $\begin{array}{l}0,19 \mathrm{~g} \\
0,38 \mathrm{~g}\end{array}$ & 2 weeks & $\begin{array}{c}\text { In vivo } \\
\text { [Open label } \\
\text { pilot] }\end{array}$ & $\begin{array}{l}9 \text { healthy adults } \\
\text { from } 37 \text { to } 42 \text { years } \\
\text { of age } \\
8 \text { elderly inpatients } \\
\text { from } 67 \text { to } 98 \text { years } \\
\text { of age }\end{array}$ & $\begin{array}{c}\text { None red wine, green } \\
\text { tea, products } \\
\text { prepared using lactic } \\
\text { bacteria } \\
62,5 \pm 4,7 \mathrm{~g} / \mathrm{d} \text { proteins, } \\
38,0 \pm 4,7 \mathrm{~g} / \mathrm{d} \text { lipids, } \\
212,0 \pm 15,0 \mathrm{~g} / \mathrm{d} \\
\text { carbohydrate } 944 \pm 1,3 \\
\mathrm{~g} / \mathrm{d} \text { sodium }, 803,9 \pm \\
105,8 \mathrm{mg} / \mathrm{d} \text { moisture, } \\
568,1 \pm \\
89,9 \mathrm{mg} / \mathrm{d} \text { calcium }\end{array}$ & $\begin{array}{l}\text { Cerebral stroke, } \\
\text { bone } \\
\text { fracture, } \\
\text { senile dementia, } \\
\text { articular } \\
\text { rheumatism }\end{array}$ & $\begin{array}{l}\text { None antibiotics } \\
\text { None antibiotics }\end{array}$ & Bifidobacterium spp. & Enterobacteriaceae & [48] \\
\hline Cocoa flavonoids & $\begin{array}{l}23 \mathrm{mg} \\
494 \mathrm{mg}\end{array}$ & 4 weeks & $\begin{array}{l}\text { In vivo } \\
\text { (Randomized, } \\
\text { double-blind, } \\
\text { placebo- } \\
\text { controlled) }\end{array}$ & $\begin{array}{c}22 \text { healthy } \\
\text { volunteers ( } 12 \text { male } \\
\text { and } 10 \text { female - } \\
\text { premenopausal ) } \\
\text { from } 18 \text { to } 50 \text { years } \\
\text { of age }\end{array}$ & $\begin{array}{l}\text { The patients did not } \\
\text { change their } \\
\text { dietary habits }\end{array}$ & & None antibiotics & $\begin{array}{l}\text { Bifidobacterium spp. } \\
\text { Lactobacillus spp. }\end{array}$ & Clostridium spp. & [50] \\
\hline
\end{tabular}


Table 2. Cont

\begin{tabular}{|c|c|c|c|c|c|c|c|c|c|c|}
\hline $\begin{array}{l}\text { Examined } \\
\text { Polyphenols }\end{array}$ & Dose & Duration & $\begin{array}{c}\text { Type of } \\
\text { Experiment }\end{array}$ & Subjects & Diet & Diseases & $\begin{array}{l}\text { Medications } \\
\text { Taken }\end{array}$ & $\begin{array}{c}\text { Stimulation of } \\
\text { Bacterial Growth }\end{array}$ & $\begin{array}{c}\text { Inhibition of } \\
\text { Bacterial Growth }\end{array}$ & Reference \\
\hline Polyphenols in wine & $272 \mathrm{~mL} / \mathrm{d}$ & 4 weeks & $\begin{array}{l}\text { In vivo } \\
\text { (Randomized, } \\
\text { crossover, } \\
\text { controlled, } \\
\text { intervention) }\end{array}$ & $\begin{array}{l}10 \text { healthy adult } \\
\text { men from } 45-50 \\
\text { years of age }\end{array}$ & $\begin{array}{l}\text { The patients did not } \\
\text { change their dietary } \\
\text { habits } \\
\begin{array}{c}\text { None alcohol and red } \\
\text { wine }\end{array}\end{array}$ & & $\begin{array}{c}\text { None antibiotics } \\
\text { and } \\
\text { supplements }\end{array}$ & $\begin{array}{c}\text { Enterococcus, } \\
\text { Prevotella, } \\
\text { Bacteroides, } \\
\text { Bifidobacterium, } \\
\text { Bacteroides uniformis, } \\
\text { Eggerthella lenta, } \\
\text { Blautia } \\
\text { coccoides-Eubacterium } \\
\text { rectale group }\end{array}$ & & [52] \\
\hline Polyphenols in wine & $272 \mathrm{~mL} / \mathrm{d}$ & 30 days & $\begin{array}{l}\text { In vivo } \\
\text { (Randomized, } \\
\text { crossover, } \\
\text { controlled } \\
\text { intervention) }\end{array}$ & $\begin{array}{l}20 \text { adult men ( } 10 \\
\text { obese and } 10 \\
\text { healthy) from } 45 \text { to } \\
50 \text { years old: }\end{array}$ & $\begin{array}{l}\text { The American Heart } \\
\text { Association dietary } \\
\text { guidelines }\end{array}$ & & $\begin{array}{c}\text { None antibiotics, } \\
\text { prebiotic, } \\
\text { probiotics, } \\
\text { symbiotics, } \\
\text { vitamin } \\
\text { supplements } \\
\text { and any } \\
\text { medical } \\
\text { treatment } \\
\text { influencing } \\
\text { intestinal } \\
\text { microbiota }\end{array}$ & $\begin{array}{l}\text { Bifidobacterium spp. } \\
\text { Lactobacillus spp. }\end{array}$ & $\begin{array}{l}\text { Enterobacter cloacae } \\
\text { Escherichia coli }\end{array}$ & [56] \\
\hline $\begin{array}{c}\text { Resveratrol } \\
\text { Epigallocatechin-3-gallate }\end{array}$ & $\begin{array}{l}80 \mathrm{mg} / \mathrm{d} \\
282 \mathrm{mg} / \mathrm{d}\end{array}$ & 12 week & $\begin{array}{l}\text { In vivo } \\
\text { (Randomized, } \\
\text { double-blind, } \\
\text { placebo- } \\
\text { controlled) } \\
\end{array}$ & $\begin{array}{c}18 \text { males and } 19 \\
\text { females from } 20 \text { to } \\
50 \text { years of age }\end{array}$ & $\begin{array}{c}<600 \mathrm{mg} \text { caffeine, }<3 \\
\text { cups green tea, }<20 \mathrm{~g} \\
\text { alcohol }\end{array}$ & $\begin{array}{l}\text { Overweight and } \\
\text { obese }\end{array}$ & $\begin{array}{l}\text { None antibiotics, } \\
\text { medication, } \\
\text { supplements }\end{array}$ & & Bacteroidetes & [57] \\
\hline $\begin{array}{l}\text { Anthocyanins } \\
\text { Gallic acid }\end{array}$ & & $24 \mathrm{~h}$ & In vitro & & & & & $\begin{array}{l}\text { Bifidobacterium spp. } \\
\text { Lactobacillus spp. }\end{array}$ & $\begin{array}{l}\text { Clostridium } \\
\text { histolyticum }\end{array}$ & [64] \\
\hline Quercetin & $\begin{array}{c}12.5,25,50 \\
75 \mu \mathrm{g} / \mathrm{mL}\end{array}$ & $24 \mathrm{~h}$ & In vitro & & & & & & $\begin{array}{c}\text { Bifidobacterium } \\
\text { catenulatum, } \\
\text { Enterococcus caccae }\end{array}$ & [73] \\
\hline $\begin{array}{l}\text { Naringenin, Naringin, Hesperetin, } \\
\text { Hesperidin, } \\
\text { Rutin, } \\
\text { Quercetin Catechin }\end{array}$ & $\begin{array}{c}20,100,250 \\
\mu \mathrm{g} / \mathrm{mL} L^{*} \\
*[\text { for quercetin } 4 \\
20,50 \mu \mathrm{g} / \mathrm{mL}]\end{array}$ & $24 \mathrm{~h}$ & In vitro & & & & & & Lactic acid bacteria & [74] \\
\hline Grapes' polyphenols & $\begin{array}{l}0.25,0.5,1 \\
\mathrm{mg} / \mathrm{mL}\end{array}$ & $24 \mathrm{~h}$ & In vitro & & & & & & $\begin{array}{l}\text { Bifidobacterium spp. } \\
\text { Lactobacillus spp. }\end{array}$ & [75] \\
\hline
\end{tabular}


Table 2. Cont.

\begin{tabular}{|c|c|c|c|c|c|c|c|c|c|c|}
\hline $\begin{array}{c}\text { Examined } \\
\text { Polyphenols }\end{array}$ & Dose & Duration & $\begin{array}{c}\text { Type of } \\
\text { Experiment }\end{array}$ & Subjects & Diet & Diseases & $\begin{array}{c}\text { Medications } \\
\text { Taken }\end{array}$ & $\begin{array}{c}\text { Stimulation of } \\
\text { Bacterial Growth }\end{array}$ & $\begin{array}{c}\text { Inhibition of } \\
\text { Bacterial Growth }\end{array}$ & Reference \\
\hline $\begin{array}{c}\text { Extracts from: } \\
\text { blackcurrant } \\
\text { blueberry } \\
\text { cranberry } \\
\text { cloudberry } \\
\text { lingonberry } \\
\text { raspberry } \\
\text { berry of sea-buckthorn } \\
\text { strawberry } \\
\text { Polyphenols: } \\
\text { Apigenin, } \\
\text { Caffeic acid, } \\
\text { (+) - Catechin, Chlorogenic acid, } \\
\text { Coumarin-3-carboxylic acid, } \\
\text { Cyanidin chloride, Delphinidin } \\
\text { chloride, } \\
\text { Ferulic acid, Isoquercetin, } \\
\text { Kaemperol, } \\
\text { Cyanidin-3-O-glucoside, } \\
\text { Luteolin, } \\
\text { Myricetin, } \\
\text { Pelargonidin chloride, } \\
\text { Quercetin dihydrate, } \\
\text { Rutin trihydrate, } \\
\text { Trans-cinnamic acid }\end{array}$ & $0,5,1,5 \mathrm{mg} / \mathrm{mL}$ & $24 \mathrm{~h}$ & In vitro & & & & & & 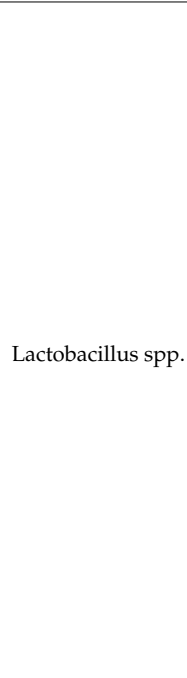 & [76] \\
\hline
\end{tabular}




\section{Conclusions}

Reviewed studies present complex interactions between polyphenol compounds and intestinal microorganism with both positive and negative consequences. The presented studies examined the influence of polyphenols on gut's microbiota in vivo and in vitro. Clinical studies, due to their design, do not give unequivocal answers. The first major limitation of the research is the number of individuals. A study group that is too small may not be enough to notice subtle changes. Another limitation is the short duration of the test. Making a comparison of the results between studies is often difficult due to differences in the accuracy of microorganism identification; some studies indicate changes at the phylum level, and others at the level of the species. In addition, the lack of clear information about the diet and lifestyle of patients means that caution should be exercised when extrapolating the results obtained. The in vitro studies were performed only on monobacterial cultures. As previously mentioned, intestinal microbiome is one of the most complex ecosystems on Earth. Biotransformation of polyphenol complexes by bacteria is still a subject of discussion and requires further studies. In respective stages, different microorganisms are responsible for transformation of polyphenols. Therefore, a lack of knowledge on this subject limits the analysis of potential benefits for human. Due to the limitations of the above-mentioned studies, further experiments are essential to examine the contribution of particular bacteria on different stages of biotransformation of polyphenol compounds and the consequences for human's health.

Author Contributions: M.W. Research concept and design; J.G. Writing the article; E.M. Data analysis and interpretation; M.P. Collection and assembly of data; M.Ś. Critical revision of the article; P.S. Critical revision of the article; E.S. Writing the article; B.M. Data analysis and interpretation. All authors have read and agreed to the published version of the manuscript.

Funding: This research received no external funding.

Conflicts of Interest: The authors declare no conflict of interest.

\section{References}

1. Bibbo, S.; Ianiro, G.; Giorgio, V.; Scaldaferri, F.; Masucci, L.; Gasbarrini, A.; Cammarota, G. The role of diet on gut microbiota composition. Eur. Rev. Med. Pharmacol. Sci. 2016, 20, 4742-4749. [PubMed]

2. Nicholson, J.; Holmes, E.; Kinross, J.; Burcelin, R.; Gibson, G.; Jia, W.; Pettersson, S. Host-Gut Microbiota Metabolic Interactions. Science 2012, 336, 1262-1267. [CrossRef] [PubMed]

3. Zeng, H.; Umar, S.; Rust, B.; Lazarova, D.; Bordonaro, M. Secondary Bile Acids and Short Chain Fatty Acids in the Colon: A Focus on Colonic Microbiome, Cell Proliferation, Inflammation, and Cancer. Int. J. Mol. Sci. 2019, 20, 1214. [CrossRef] [PubMed]

4. Raman, M.; Ambalam, P.; Doble, M. Probiotics and Bioactive Carbohydrates in Colon Cancer Management. In Probiotics and Bioactive Carbohydrates in Colon Cancer Management; Springer: New Delhi, India, 2016.

5. Tremaroli, V.; Bäckhed, F. Functional interactions between the gut microbiota and host metabolism. Nature 2012, 489, 242-249. [CrossRef] [PubMed]

6. Hooper, L.V.; Littman, D.R.; MacPherson, A.J. Interactions Between the Microbiota and the Immune System. Science 2012, 336, 1268-1273. [CrossRef] [PubMed]

7. Mandal, P. Molecular mechanistic pathway of colorectal carcinogenesis associated with intestinal microbiota. Anaerobe 2018, 49, 63-70. [CrossRef]

8. Turnbaugh, P.J.; Ridaura, V.K.; Faith, J.J.; Rey, F.E.; Knight, R.; Gordon, J.I. The Effect of Diet on the Human Gut Microbiome: A Metagenomic Analysis in Humanized Gnotobiotic Mice. Sci. Transl. Med. 2009, 1, 6 ra14. [CrossRef]

9. Modi, S.R.; Collins, J.J.; Relman, D.A. Antibiotics and the gut microbiota. J. Clin. Investig. 2014, 124, 4212-4218. [CrossRef]

10. Reynolds, M.A.; Prudencio, A.; Aichelmann-Reidy, M.E.; Woodward, K.; Uhrich, K. Non-Steroidal Anti-inflammatory Drug (NSAID)-Derived Poly(anhydrideesters) in Bone and Periodontal Regeneration. Curr. Drug Deliv. 2007, 4, 233-239. [CrossRef] 
11. Hirata, S.; Kunisawa, J. Gut microbiome, metabolome, and allergic diseases. Allergol Int. 2017, 66, 523-528. [CrossRef]

12. Cenit, M.C.; Matzaraki, V.; Tigchelaar, E.; Zhernakova, A. Rapidly expanding knowledge on the role of the gut microbiome in health and disease. Biochim. et Biophys. Acta (BBA) Mol. Basis Dis. 2014, 1842, 1981-1992. [CrossRef] [PubMed]

13. Oriach, C.S.; Robertson, R.C.; Stanton, C.; Cryan, J.F.; Dinan, T.G. Food for thought: The role of nutrition in the microbiota-gut-brain axis. Clin. Nutr. Exp. 2016, 6, 25-38. [CrossRef]

14. Sharon, G.; Sampson, T.R.; Geschwind, D.H.; Mazmanian, S.K. The Central Nervous System and the Gut Microbiome. Cell 2016, 167, 915-932. [CrossRef] [PubMed]

15. Martinez, J.A.; Ramos-Lopez, O.; Riezu-Boj, J.-I.; Milagro, F.I.; Martinez, J.A. Diet, Gut Microbiota, and Obesity: Links with Host Genetics and Epigenetics and Potential Applications. Adv. Nutr. 2019, 10, S17-S30.

16. Ozdal, T.; Sela, D.; Ulrih, N.P.; Boyacioglu, D.; Chen, F.; Capanoglu, E. The Reciprocal Interactions between Polyphenols and Gut Microbiota and Effects on Bioaccessibility. Nutrients 2016, 8, 78. [CrossRef] [PubMed]

17. Tsao, R. Chemistry and Biochemistry of Dietary Polyphenols. Nutrients 2010, 2, 1231-1246. [CrossRef] [PubMed]

18. Colomer, R.; Sarrats, A.; Lupu, R.; Puig, T. Natural Polyphenols and their Synthetic Analogs as Emerging Anticancer Agents. Curr. Drug Targets 2017, 18, 147-159. [CrossRef]

19. Wang, T.-Y.; Li, Q.; Bi, K. Bioactive flavonoids in medicinal plants: Structure, activity and biological fate. Asian J. Pharm. Sci. 2018, 13, 12-23. [CrossRef]

20. Farhadi, F.; Khameneh, B.; Iranshahi, M.; Iranshahy, M. Antibacterial activity of flavonoids and their structure-activity relationship: An update review. Phytother. Res. 2018, 33, 13-40. [CrossRef]

21. Fang, Y.; Liang, F.; Liu, K.; Qaiser, S.; Pan, S.; Xu, X. Structure characteristics for intestinal uptake of flavonoids in Caco-2 cells. Food Res. Int. 2017, 105, 353-360. [CrossRef]

22. Murota, K.; Nakamura, Y.; Uehara, M. Flavonoid metabolism: The interaction of metabolites and gut microbiota. Biosci. Biotechnol. Biochem. 2018, 82, 600-610. [CrossRef] [PubMed]

23. Oteiza, P.I.; Fraga, C.; Mills, D.A.; Taft, D. Flavonoids and the gastrointestinal tract: Local and systemic effects. Mol. Asp. Med. 2018, 61, 41-49. [CrossRef] [PubMed]

24. Rowland, I.; Gibson, G.; Heinken, A.; Scott, K.; Swann, J.; Thiele, I.; Tuohy, K. Gut microbiota functions: Metabolism of nutrients and other food components. Eur. J. Nutr. 2018, 57, 1-24. [CrossRef] [PubMed]

25. Tomás-Barberán, F.A.; Selma, M.V.; Espín, J.C. Interactions of gut microbiota with dietary polyphenols and consequences to human health. Curr. Opin. Clin. Nutr. Metab. Care 2016, 19, 471-476. [CrossRef]

26. Joseph, S.V.; Edirisinghe, I.; Burton-Freeman, B.M. Fruit Polyphenols: A Review of Anti-inflammatory Effects in Humans. Crit. Rev. Food Sci. Nutr. 2015, 56, 419-444. [CrossRef]

27. Pérez-Jiménez, J.; Neveu, V.; Voß, F.; Scalbert, A. Identification of the 100 richest dietary sources of polyphenols: An application of the Phenol-Explorer database. Eur. J. Clin. Nutr. 2010, 64, S112-S120. [CrossRef]

28. Khan, N.; Mukhtar, H. Tea polyphenols for health promotion. Life Sci. 2007, 81, 519-533. [CrossRef]

29. Leopoldini, M.; Nino, R.; Toscano, M. The molecular basis of working mechanism of natural polyphenolic antioxidants. Food Chem. 2011, 125, 288-306. [CrossRef]

30. Wang, T.; Jonsdottir, R.; Olafsdottir, G. Total phenolic compounds, radical scavenging and metal chelation of extracts from Icelandic seaweeds. Food Chem. 2009, 116, 240-248. [CrossRef]

31. Brillas, E.; Sirés, I.; Oturan, M.A. Electro-Fenton Process and Related Electrochemical Technologies Based on Fenton's Reaction Chemistry. Chem. Rev. 2009, 109, 6570-6631. [CrossRef]

32. Trujillo, D.; Font, X.; Sanchez, A. Use of Fenton reaction for the treatment of leachate from composting of different wastes. J. Hazard. Mater. 2006, 138, 201-204. [CrossRef]

33. Ajiboye, T.O.; Aliyu, M.; Isiaka, I.; Haliru, F.; Ibitoye, O.; Uwazie, J.; Muritala, H.; Bello, S.; Yusuf, I.; Mohammed, A. Contribution of reactive oxygen species to (+)-catechin-mediated bacterial lethality. Chem. Interactions 2016, 258, 276-287. [CrossRef] [PubMed]

34. Zhang, H.; Tsao, R. Dietary polyphenols, oxidative stress and antioxidant and anti-inflammatory effects. Curr. Opin. Food Sci. 2016, 8, 33-42. [CrossRef]

35. Zhou, Y.; Zheng, J.; Li, Y.; Xu, N.-P.; Li, S.; Chen, Y.-M.; Li, H.-B. Natural Polyphenols for Prevention and Treatment of Cancer. Nutrients 2016, 8, 515. [CrossRef] [PubMed]

36. Rothwell, J.A.; Knaze, V.; Zamora-Ros, R. Polyphenols: Dietary assessment and role in the prevention of cancers. Curr. Opin. Clin. Nutr. Metab. Care 2017, 20, 512-521. [CrossRef] [PubMed] 
37. Lecci, R.M.; Logrieco, A.; Leone, A. Pro-oxidative action of polyphenols as action mechanism for their pro-apoptotic activity. Anti-Cancer Agents Med. Chem. 2014, 14, 1363-1375. [CrossRef]

38. Tzounis, X.; Vulevic, J.; Kuhnle, G.; George, T.; Leonczak, J.; Gibson, G.R.; Kwik-Uribe, C.; Spencer, J.P. Flavanol monomer-induced changes to the human faecal microflora. Br. J. Nutr. 2007, 99, 782-792. [CrossRef]

39. Shortt, C.; Hasselwander, O.; Meynier, A.; Nauta, A.; Fernández, E.N.; Putz, P.; Rowland, I.; Swann, J.; Türk, J.; Vermeiren, J.; et al. Systematic review of the effects of the intestinal microbiota on selected nutrients and non-nutrients. Eur. J. Nutr. 2017, 57, 25-49. [CrossRef]

40. Koh, A.; De Vadder, F.; Kovatcheva-Datchary, P.; Bäckhed, F. From Dietary Fiber to Host Physiology: Short-Chain Fatty Acids as Key Bacterial Metabolites. Cell 2016, 165, 1332-1345. [CrossRef]

41. Wilson, M. Short-chain fatty acids. In Microbial Inhabitants of Humans; Cambridge University Press: Cambridge, UK, 2005; pp. 388-390.

42. Redondo, N.; Gheorghe, A.; Díaz, L.E.; Villavisencio, B.; Marcos, A.; Nova, E. Associations of Probiotic Fermented Milk (PFM) and Yogurt Consumption with Bifidobacterium and Lactobacillus Components of the Gut Microbiota in Healthy Adults. Nutrients 2019, 11, 651. [CrossRef] [PubMed]

43. Ma, N.; Tian, Y.; Wu, Y.; Ma, X. Contributions of the Interaction between Dietary Protein and Gut Microbiota to Intestinal Health. Curr. Protein Pept. Sci. 2017, 18, 1. [CrossRef] [PubMed]

44. Zhao, J.; Zhang, X.; Liu, H.; Brown, M.A.; Qiao, S. Dietary Protein and Gut Microbiota Composition and Function. Curr. Protein Pept. Sci. 2019, 20, 145-154. [CrossRef] [PubMed]

45. Nowak, A.; Lubudisz, Z. Karcynogenna aktywność mikroorganizmów jelitowych. Żywność Nauka Technologia Jakość 2008, 6, 25-39.

46. Goto, K.; Kanaya, S.; Nishikawa, T.; Hara, H.; Terada, A.; Ishigami, T.; Hara, Y. The effects of tea catechins on fecal flora of elderly residents in long-term care facilities. J. Nutr. Sci. Vitaminol. (Tokyo). 1999, 45, 135-141. [CrossRef] [PubMed]

47. Lee, H.C.; Jenner, A.M.; Low, C.S.; Lee, Y.-K. Effect of tea phenolics and their aromatic fecal bacterial metabolites on intestinal microbiota. Res. Microbiol. 2006, 157, 876-884. [CrossRef] [PubMed]

48. Yamakoshi, J.; Tokutake, S.; Kikuchi, M. Effect of Proanthocyanidin-Rich Extract from Grape Seeds on Human Fecal Flora and Fecal Odor. Microb Ecol Health Dis. 2001, 13, 25-31.

49. Lee, E.-S.; Song, E.-J.; Nam, Y.-D.; Lee, S.-Y. Probiotics in human health and disease: From nutribiotics to pharmabiotics. J. Microbiol. 2018, 56, 773-782. [CrossRef]

50. Tzounis, X.; Rodriguez-Mateos, A.; Vulevic, J.; Gibson, G.R.; Kwik-Uribe, C.; Spencer, J.P. Prebiotic evaluation of cocoa-derived flavanols in healthy humans by using a randomized, controlled, double-blind, crossover intervention study. Am. J. Clin. Nutr. 2010, 93, 62-72. [CrossRef]

51. Requena, T.; Monagas, M.; Pozo-Bayon, M.A.; Martin-Alvarez, P.; Bartolomé, B.; Del Campo, R.; Ávila, M.; Martínez-Cuesta, M.C.; Peláez, C.; Moreno-Arribas, M. Perspectives of the potential implications of wine polyphenols on human oral and gut microbiota. Trends Food Sci. Technol. 2010, 21, 332-344. [CrossRef]

52. Ortuño, M.I.Q.; Boto-Ordóñez, M.; Murri, M.; Gómez-Zumaquero, J.M.; Clemente-Postigo, M.; Estruch, R.; Diaz, F.C.; Andres-Lacueva, C.; Tinahones, F.J. Influence of red wine polyphenols and ethanol on the gut microbiota ecology and biochemical biomarkers. Am. J. Clin. Nutr. 2012, 95, 1323-1334. [CrossRef]

53. Melanie, H.; Susilowati, A.; Maryati, Y. Fermented inulin hydrolysate by Bifidobacterium breve as cholesterol binder in functional food application. Int. Symp. Appl. Chem. 2016, 1803, 259-266.

54. Guo, Z.; Zhang, J.; Wang, Z.; Ang, K.Y.; Huang, S.; Hou, Q.; Su, X.; Qiao, J.; Zheng, Y.; Wang, L.; et al. Intestinal Microbiota Distinguish Gout Patients from Healthy Humans. Sci. Rep. 2016, 6, 20602. [CrossRef]

55. Melander, O.; Newton-Cheh, C.; Almgren, P.; Hedblad, B.; Berglund, G.; Engström, G.; Persson, M.; Smith, J.G.; Magnusson, M.; Christensson, A.; et al. Novel and Conventional Biomarkers for Prediction of Incident Cardiovascular Events in the Community. JAMA. 2009, 302, 49-57. [CrossRef] [PubMed]

56. Moreno-Indias, I.; Sanchez-Alcoholado, L.; Pérez-Martínez, P.; Andres-Lacueva, C.; Cardona, F.; Tinahones, F.J.; Ortuño, M.I.Q. Red wine polyphenols modulate fecal microbiota and reduce markers of the metabolic syndrome in obese patients. Food Funct. 2016, 7, 1775-1787. [CrossRef]

57. Most, J.; Penders, J.; Lucchesi, M.; Goossens, G.H.; E Blaak, E. Gut microbiota composition in relation to the metabolic response to 12-week combined polyphenol supplementation in overweight men and women. Eur. J. Clin. Nutr. 2017, 71, 1040-1045. [CrossRef] [PubMed]

58. Ferreira-Halder, C.V.; Faria, A.V.S.; Andrade, S.S. Action and function of Faecalibacterium prausnitzii in health and disease. Best Pract. Res. Clin. Gastroenterol. 2017, 31, 643-648. [CrossRef] [PubMed] 
59. Zhang, M.; Zhou, L.; Wang, Y.; Dorfman, R.G.; Tang, D.; Xu, L.; Pan, Y.; Zhou, Q.; Li, Y.; Yin, Y.; et al. Faecalibacterium prausnitzii produces butyrate to decrease c-Myc-related metabolism and Th17 differentiation by inhibiting histone deacetylase 3. Int. Immunol. 2019, 31, 499-514. [CrossRef]

60. Lopez-Siles, M.; Duncan, S.H.; Garcia-Gil, J.; Martinez-Medina, M. Faecalibacterium prausnitzii: From microbiology to diagnostics and prognostics. ISME J. 2017, 11, 841-852. [CrossRef]

61. Lopez-Siles, M.; Enrich-Capó, N.; Aldeguer, X.; Sabat-Mir, M.; Duncan, S.H.; Garcia-Gil, L.J.; Martinez-Medina, M. Alterations in the Abundance and Co-occurrence of Akkermansia muciniphila and Faecalibacterium prausnitzii in the Colonic Mucosa of Inflammatory Bowel Disease Subjects. Front. Microbiol. 2018, 8, 281. [CrossRef]

62. Biedermann, L.; Mwinyi, J.; Scharl, M.; Frei, P.; Zeitz, J.; Kullak- Ublick, G.A.; Vavricka, S.R.; Fried, M.; Weber, A.; Humpf, H.U.; et al. Bilberry ingestion improves disease activity in mild to moderate ulcerative colitis - An open pilot study. J. Crohns Colitis. 2013, 7, 271-279. [CrossRef]

63. Dryden, G.; Lam, A.; Beatty, K.; Qazzaz, H.H.; McClain, C.J. A Pilot Study to Evaluate the Safety and Efficacy of an Oral Dose of (-)-Epigallocatechin-3-Gallate-Rich Polyphenon E in Patients With Mild to Moderate Ulcerative Colitis. Inflamm. Bowel Dis. 2013, 19, 1904-1912. [CrossRef] [PubMed]

64. Hidalgo, M.; Concha, M.J.O.; Kolida, S.; Walton, G.E.; Kallithraka, S.; Spencer, J.P.E.; Gibson, G.R.; De Pascual-Teresa, S. Metabolism of Anthocyanins by Human Gut Microflora and Their Influence on Gut Bacterial Growth. J. Agric. Food Chem. 2012, 60, 3882-3890. [CrossRef] [PubMed]

65. Eslami, M.; Yousefi, B.; Kokhaei, P.; Hemati, M.; Nejad, Z.R.; Arabkari, V.; Namdar, A. Importance of probiotics in the prevention and treatment of colorectal cancer. J. Cell. Physiol. 2019, 234, 17127-17143. [CrossRef] [PubMed]

66. Hervert-Hernández, D.; Goñi, I. Dietary Polyphenols and Human Gut Microbiota: A Review. Food Rev. Int. 2011, 27, 154-169. [CrossRef]

67. Puupponen-Pimiä, R.; Nohynek, L.; Hartmann-Schmidlin, S.; Kähkönen, M.; Heinonen, M.; Maatta-Riihinen, K.; Oksman-Caldentey, K.-M. Berry phenolics selectively inhibit the growth of intestinal pathogens. J. Appl. Microbiol. 2005, 98, 991-1000. [CrossRef]

68. Kemperman, R.; Bolca, S.; Roger, L.C.; Vaughan, E.E. Novel approaches for analysing gut microbes and dietary polyphenols: Challenges and opportunities. Microbiol. 2010, 156, 3224-3231. [CrossRef]

69. Anna, V.S.; Biondo, E.; Kolchinski, E.M.; Da Silva, L.F.S.; Correa, A.P.F.; Bach, E.; Brandelli, A. Total Polyphenols, Antioxidant, Antimicrobial and Allelopathic Activities of Spend Coffee Ground Aqueous Extract. Waste Biomass Valorization 2016, 8, 439-442.

70. Coppo, E.; Marchese, A. Antibacterial activity of polyphenols. Curr. Pharm. Biotechnol. 2014, 15, 380-390. [CrossRef]

71. Nazzaro, F.; Fratianni, F.; Coppola, R. Quorum Sensing and Phytochemicals. Int. J. Mol. Sci. 2013, 14, 12607-12619. [CrossRef]

72. Cardona, F.; Andres-Lacueva, C.; Tulipani, S.; Tinahones, F.J.; Ortuño, M.I.Q. Benefits of polyphenols on gut microbiota and implications in human health. J. Nutr. Biochem. 2013, 24, 1415-1422. [CrossRef]

73. Firrman, J.; Liu, L.; Zhang, L.; Argoty, G.A.; Wang, M.; Tomasula, P.; Kobori, M.; Pontious, S.; Xiao, W. The effect of quercetin on genetic expression of the commensal gut microbes Bifidobacterium catenulatum, Enterococcus caccae and Ruminococcus gauvreauii. Anaerobe 2016, 42, 130-141. [CrossRef] [PubMed]

74. Duda-Chodak, A. The inhibitory effect of polyphenols on human gut microbiota. J. Physiol. Pharmacol. Off. J. Pol. Physiol. Soc. 2012, 63, 497-503.

75. Tabasco, R.; Sánchez-Patán, F.; Monagas, M.; Bartolomé, B.; Moreno-Arribas, M.V.; Peláez, C.; Requena, T. Effect of grape polyphenols on lactic acid bacteria and bifidobacteria growth: Resistance and metabolism. Food Microbiol. 2011, 28, 1345-1352. [CrossRef] [PubMed]

76. Puupponen-Pimiä, R.; Nohynek, L.; Meier, C.; Kahkonen, M.; Heinonen, M.; Hopia, A.; Oksman-Caldentey, K.-M. Antimicrobial properties of phenolic compounds from berries. J. Appl. Microbiol. 2001, 90, 494-507. [CrossRef] [PubMed]

(C) 2020 by the authors. Licensee MDPI, Basel, Switzerland. This article is an open access article distributed under the terms and conditions of the Creative Commons Attribution (CC BY) license (http://creativecommons.org/licenses/by/4.0/). 